Article

\title{
Reducing Immunoreactivity of Gliadins and Coeliac-Toxic Peptides Using Peptidases from L. acidophilus $5 \mathrm{e} 2$ and $A$. niger
}

\author{
Bartosz Brzozowski *, Katarzyna Stasiewicz, Mateusz Ostolski and Marek Adamczak (D) \\ Department of Food Biotechnology, Faculty of Food Sciences, University of Warmia and Mazury in Olsztyn, \\ 10-718 Olsztyn, Poland; katarzyna.stasiewicz@uwm.edu.pl (K.S.); mateusz.ostolski@uwm.edu.pl (M.O.); \\ marek.adamczak@uwm.edu.pl (M.A.) \\ * Correspondence: bartosz.brzozowski@uwm.edu.pl
}

Received: 21 July 2020; Accepted: 10 August 2020; Published: 11 August 2020

check for updates

\begin{abstract}
Wheat storage proteins and products of their hydrolysis may cause coeliac sprue in genetically predisposed individuals with high expression of main histocompatibility complex HLA-DQ2 or DQ8, since by consuming wheat, they become exposed to proline- $(\mathrm{P})$ and glutamine (Q)-rich gluten. In bread-making, the hydrolysis of gliadins and coeliac-toxic peptides occurs with varied efficiency depending on the fermentation $\mathrm{pH}$ and temperature. Degradation of gliadins catalysed by Lactobacillus acidophilus $5 \mathrm{e} 2$ peptidases and a commercial prolyl endopeptidase synthesised by $A$. niger, carried out at $\mathrm{pH} 4.0$ and $37^{\circ} \mathrm{C}$, reduces the gliadin concentration over 110 -fold and decreases the relative immunoreactivity of the hydrolysate to $0.9 \%$ of its initial value. Hydrolysis of coeliac-toxic peptides: LGQQQPFPPQQPY (P1) and PQPQLPYPQPQLP (P2) under the same conditions occurs with the highest efficiency, reaching $99.8 \pm 0.0 \%$ and $97.5 \pm 0.1 \%$, respectively. The relative immunoreactivity of peptides $\mathrm{P} 1$ and $\mathrm{P} 2$ was $0.8 \pm 0.0 \%$ and $3.2 \pm 0.0 \%$, respectively. A mixture of peptidases from L. acidophilus $5 \mathrm{e} 2$ and A. niger may be used in wheat sourdough fermentation to reduce the time needed for degradation of proteins and products of their hydrolysis.
\end{abstract}

Keywords: peptidase; prolyl endopeptidase; L. acidophilus; gliadin immunoreactivity; coeliac disease

\section{Introduction}

Coeliac disease (CD) is a chronic enteropathy leading to villous atrophy and crypt hyperplasia. Epidemiological studies estimate that it affects 1-3\% of the human population, including children and adults [1]. In genetically predisposed individuals, the consumption of gluten proteins derived from wheat, rye or barley triggers damage to the small intestine wall and leads to reduced absorption of nutrients $[1,2]$. The most effective way of inhibiting the development of $C D$ is adopting a gluten-free diet. Peptides released from wheat storage proteins, i.e., monomeric $\alpha-, \beta-, \gamma$ - and $\omega$-gliadins and polymeric low- (LMW) and high-molecular weight (HMW) glutenins, comprise amino acid sequences recognised by the immune system, which are responsible for coeliac pathogenesis and resistant to digestion by the human gastrointestinal tract enzymes $[3,4]$.

However, there is an alternative to the dietary withdrawal of gluten. Coeliac-toxic and immunoreactive polypeptide chains can be modified or removed during food processing using enzymes and/or microorganisms [5-9]. The following proline- and glutamine-specific peptidases could be used: prolyl endopeptidase (EC 3.4.21.26) synthesised by Sphingomonas capsulata, Myxococcus xanthus, Flavobacterium meningosepticum and Aspergillus niger, peptidases synthesised by Pseudomonas aeruginosa, lactic acid bacteria (LAB) as well as caricain (EC 3.4.22.30) and cereal grain-native peptidases [5,6,8-14].

LAB involved in sourdough fermentation are characterised by low activity of extracellular peptidases. These bacteria also synthesise intracellular aminopeptidases, dipeptidases and tripeptidases, 
including proline-specific peptidases, which break down gluten [15]. However, proteins must be first hydrolysed to peptides and then transported through a bacterial cell wall to be further degraded by intracellular peptidases [16]. Initial break down of gluten to peptides is carried out by cereal native peptidases, which are activated during dough acidification by LAB $[15,17]$. Gluten hydrolysis, first by cereal-native and then bacterial peptidases, is time consuming and lasts from 24 to $48 \mathrm{~h}[18,19]$. To increase the rate of gluten hydrolysis and the degree of degradation of peptides involved in coeliac pathogenesis, an addition of fungal proteolytic enzymes and peptidases from germinating cereal kernels or LAB cytoplasmic fraction was applied [5,20-23].

The use of fungal and LAB peptidases can degrade gluten to concentrations below $10 \mathrm{mg} / \mathrm{kg}$ of sourdough [23]. Due to gluten hydrolysis by fungal peptidases, 4- to 40-amino-acid-long peptides are released, transported inside bacterial cells and then hydrolysed to amino acids by intracellular peptidases [20].

Preliminary clinical studies conducted by Greco et al. [24] confirmed the effectiveness of coeliac-toxic peptide degradation in the course of wheat flour fermentation with L. alimentarius 15M, L. brevis 14G, L. sanfranciscensis 7A, L. hilgardii $51 \mathrm{~B}$ or a mixture of six strains of L. sanfranciscensis (LS3, LS10, LS19, LS23, LS38 and LS47) with an addition of peptidases synthesised by A. oryzae and A. niger. A 60-day diet, including bread produced from sourdough with a gluten concentration below $10 \mathrm{mg} / \mathrm{kg}$, did not cause serological or morphological changes in coeliac patients [24]. The hydrolysis could be performed simultaneously or as a sequential process $[5,8,10,20,23,24]$. Two-step protein hydrolysis with peptidases synthesised by A. oryzae and A. niger and peptidases from LAB isolated from sourdough ensures a reduction in the immunoreactivity of gliadins and glutenins by $66 \%$ and $20 \%$, respectively. In the next step, the degraded proteins are subjected to hydrolysis by pepsin and trypsin, decreased K562(S)-cell agglutination and T-cell stimulation [8].

Moreover, enzymes extracted from germinating cereal kernels are useful in gluten degradation to peptides. Germinating wheat kernel extract offering the activity of mainly prolyl oligopeptidase and dipeptide peptidase IV was applied in the initial hydrolysis of proteins of wheat dough. Next, the same wheat dough was subjected to fermentation with L. brevis L62, following which the concentration of gliadins in the obtained dough was reduced to $1200 \mathrm{mg} / \mathrm{kg}$ [25].

There have been numerous reports on the successful degradation of wheat kernel proteins, including gliadins, in the course of fermentation with LAB in traditional bread-making technology. Bacterial strains such as L. alimentarius $15 \mathrm{M}$, L. brevis $14 \mathrm{G}$, L. sanfranciscensis $7 \mathrm{~A}$ and L. hilgardii $51 \mathrm{~B}$ are capable of breaking down albumins, globulins and gliadins (except glutenins) during the process of fermentation $\left(8 \mathrm{~h}, 37^{\circ} \mathrm{C}\right)$ [26]. Peptidase preparations obtained from the biomass of these bacteria can hydrolyse a coeliac-toxic peptide $\alpha$ (31-43)-gliadin and a coeliac-toxic 33-mer peptide resistant to enzymatic digestion of the human gastrointestinal tract [21,26].

Wieser et al. [27] demonstrated that it was the acidic peptidase present in flour which was responsible for wheat protein degradation in sourdough and not the fermentation $\left(24 \mathrm{~h}, 30^{\circ} \mathrm{C}\right)$ carried out with L. sakei TMW1.22, L. plantarum TMW1.468 or L. sanfranciscensis TMW1.53.

Enzymatic hydrolysis of proteins and peptides during fermentation of wheat sourdough should be carried out simultaneously, quickly and efficiently for technological reasons. The authors of the present paper previously found a $3 \mathrm{~h}$ hydrolysis of wheat dough conducted at $30^{\circ} \mathrm{C}$ with peptidases ( $10 \mathrm{U} / \mathrm{g}$ of substrate) from L. acidophilus $5 \mathrm{e} 2$ or prolyl endopeptidase (10 U/g of substrate) from A. niger to reduce protein immunoreactivity by $46.6 \%$ and $36.2 \%$, respectively [10]. However, products of wheat protein hydrolysis, regardless of the enzyme preparation used, contained a high concentration of coeliac-toxic QQPFP peptide (over $20 \mathrm{mg} / \mathrm{kg}$ acceptable for "gluten-free" foods) [10]. An extension of the reaction time to $6 \mathrm{~h}$ led to an increase in protein hydrolysis efficiency and a further decrease in the peptide immunoreactivity to $83.9 \%$ and $51.9 \%$, respectively, for samples hydrolysed by peptidases obtained from L. acidophilus 5e2 and prolyl endopeptidase synthesised by A. niger [5]. Although these peptidases effectively hydrolyse wheat proteins, there is no information about hydrolysis of released peptides. These peptides are resistant to the action of human gastrointestinal tract enzymes and are 
involved in the pathogenesis of coeliac disease. On the basis of preliminary experiments, it is proposed to hydrolyse the substrate using a dose of enzymes of $100 \mathrm{U} / \mathrm{g}$ in the reaction conditions specific for the production of wheat sourdough bread.

This study analysed the possibility of the simultaneous hydrolysis of gliadins and coeliac-toxic peptides catalysed by a mixture of peptidases synthesised by L. acidophilus $5 \mathrm{e} 2$ and A. niger.

\section{Results and Discussion}

\subsection{Hydrolysis of Gliadins}

The application of LAB strains in wheat protein degradation does not always prove to be a reliable solution. For example, a very low yield of gluten hydrolysis was obtained using protease-synthesising biomass of L. sakei TMW 1.22, L. plantarum TMW 1.468 and L. sanfranciscensis TMW 1.53 isolated from sourdough [27]. Gerez et al. [28] isolated from sourdough 42 LAB strains containing L. brevis, L. curvatus, L. fermentum, L. plantarum, L. reuteri, Pediococcus acidilactici and P. pentosaceus and selected P. pentosaceus CRL 797 and L. plantarum CRL 759 for gluten hydrolysis. The efficiency of cereal protein hydrolysis can be enhanced by combining enzymes synthesised by several LAB strains $[18,21,28]$ or by adding fungal peptidases $[8,20,23,24]$.

In the present study, L. acidophilus 5e2 strain synthesised aminopeptidases, carboxypeptidases and endopeptidases, including prolyl-specific peptidases which are essential in the degradation of proline and glutamine-rich immunoreactive peptides (Table 1). A mixture composed of peptidases synthesised by L. acidophilus $5 \mathrm{e} 2$ and prolyl endopeptidase from $A$. niger was used to conduct the hydrolysis of gliadins isolated from Nawra variety wheat.

Table 1. Characteristics of peptidases from L. acidophilus 5e2 (LA) and prolyl endopeptidase from A. niger (PEP) used for gliadin hydrolysis.

\begin{tabular}{|c|c|c|c|}
\hline Enzyme & Substrate & $\begin{array}{c}\text { LA Activity } \\
\text { (U/mg) }\end{array}$ & $\begin{array}{c}\text { PEP Activity } \\
\text { (U/mg) }\end{array}$ \\
\hline Endopeptidase $^{2}$ & Acasein & $4.6 \pm 0.1$ & n.d. ${ }^{5}$ \\
\hline Carboxypeptidase $^{3}$ & Z-Phe-Ala & $1.3 \pm 0.1$ & n.d. \\
\hline Aminopeptidase 4 & Leu- $p \mathrm{Na}$ & $452.5 \pm 0.9$ & n.d. \\
\hline Prolyl endopeptidase 4 & Z-Gly-Pro- $p \mathrm{Na}$ & $15.4 \pm 0.2$ & $152.4 \pm 0.8$ \\
\hline \multirow{2}{*}{ X-Prolyl-dipeptidyl-aminopeptidase ${ }^{4}$} & Gly-Pro- $p \mathrm{Na}$ & $11,028.9 \pm 1.2$ & n.d. \\
\hline & Arg-Pro- $p \mathrm{Na}$ & $398.1 \pm 0.6$ & n.d. \\
\hline Proline iminopeptidase ${ }^{4}$ & Pro- $p \mathrm{Na}$ & $1.6 \pm 0.1$ & n.d. \\
\hline
\end{tabular}

${ }^{1}$ Results are expressed as mean \pm standard deviation calculated from three independent analyses. ${ }^{2}$ The unit of endopeptidase activity was defined as an increase in sample absorbance by 0.01 at $440 \mathrm{~nm}$ within $1 \mathrm{~h}$ at $37^{\circ} \mathrm{C}$ and at $\mathrm{pH} 7.0{ }^{3}$ The unit of carboxypeptidase activity was expressed as $1 \mu \mathrm{mol}$ of alanine released within $1 \mathrm{~min}$ at $37^{\circ} \mathrm{C}$ and at $\mathrm{pH} 7.0 .{ }^{4}$ The units of other peptidase activities were expressed as $1 \mu \mathrm{mol}$ of $p$-nitroaniline $(p \mathrm{Na})$ released within $1 \mathrm{~min}$ at $37^{\circ} \mathrm{C}$ and at $\mathrm{pH} 7.0 .{ }^{5}$ n.d. not determined.

Protein samples were effectively hydrolysed under analysed conditions and the highest degree of substrate hydrolysis of $74.0 \pm 1.2 \%$ was obtained after a $3 \mathrm{~h}$ reaction at $37^{\circ} \mathrm{C}$ and $\mathrm{pH} 4.0$ (Table 2). The degree of hydrolysis of the gliadin samples performed under other conditions was statistically lower $(p<0.05$, ANOVA, Bonferroni test) and ranged from $49.9 \pm 0.8$ to $66.4 \pm 0.7 \%$. An increase in the reaction mixture acidity from $\mathrm{pH} 6.0$ to 4.0 caused a statistically significant increase $(p<0.05$, ANOVA, Bonferroni test) in the degree of protein hydrolysis by $33.0 \%$ and $20.1 \%$, respectively, for samples incubated at 30 and $37^{\circ} \mathrm{C}$. Moreover, an increase in the reaction temperature from 30 to $37^{\circ} \mathrm{C}$ promoted substrate hydrolysis and led to a statistically significant increase $(p<0.05$, ANOVA, Bonferroni test) in the protein degradation degree by $11.4 \%$ and $23.4 \%$, respectively, for the reaction mixture acidity of $\mathrm{pH} 4.0$ and 6.0. The observations of the present study were confirmed by Greco et al. [24] who, in a two-step hydrolysis of gluten, obtained a product with a gluten concentration below $10 \mathrm{mg} / \mathrm{kg}$, which is safe for coeliac individuals. Gluten and oligopeptides, including a 33-mer coeliac-toxic peptide derived from an $\alpha$-gliadin, were subjected to initial hydrolysis with peptidases synthesised by 
A. oryzae and A. niger and then further degraded by bacterial endopeptidases from Lactobacillus genus. The application of substrate-specific prolyl endopeptidase from $A$. niger, which exhibits optimum activity at $\mathrm{pH} 4.0-5.0$, hydrolysed coeliac-toxic oligopeptides as well as proline-rich immunoreactive fragments of gliadins and glutenins [29].

Table 2. Effect of reaction conditions on the degree of hydrolysis ( $\mathrm{DH}, \%)$, concentration of a QQPFP sequence $(C, \mathrm{mg} / \mathrm{kg})$, effective immunoreactivity $(\mathrm{EI}, \mu \mathrm{g} / \mathrm{mg}$ ) and relative immunoreactivity (RI, \%) of gliadins hydrolysed by a mixture of peptidases from L. acidophilus $5 \mathrm{e} 2$ and A. niger.

\begin{tabular}{|c|c|c|c|c|}
\hline Hydrolysis Parameters & DH (\%) & $C(\mathrm{mg} / \mathrm{kg})$ & EI $(\mu \mathrm{g} / \mathrm{mg})$ & RI (\%) \\
\hline Control & $0.0 \pm 0.0 \mathrm{a}^{1}$ & $47,689.8 \pm 221.1 \mathrm{a}$ & $269,412.5 \pm 4831.0 \mathrm{a}$ & $100.00 \pm 0.38 \mathrm{a}$ \\
\hline $30^{\circ} \mathrm{C} ; \mathrm{pH} 4$ & $66.4 \pm 0.7 \mathrm{~d}$ & $1893.2 \pm 48.1 \mathrm{~d}$ & $0.4 \pm 0.0 \mathrm{c}$ & $3.97 \pm 0.08 c$ \\
\hline $30^{\circ} \mathrm{C} ; \mathrm{pH} 6$ & $49.9 \pm 0.8 b$ & $16,097.5 \pm 118.1 \mathrm{~b}$ & $4.2 \pm 0.1 \mathrm{~b}$ & $33.55 \pm 0.20 b$ \\
\hline $37^{\circ} \mathrm{C} ; \mathrm{pH} 4$ & $74.0 \pm 1.2 \mathrm{e}$ & $432.2 \pm 4.3 \mathrm{e}$ & $0.1 \pm 0.0 \mathrm{~d}$ & $0.91 \pm 0.01 \mathrm{~d}$ \\
\hline $37^{\circ} \mathrm{C} ; \mathrm{pH} 6$ & $61.6 \pm 1.6 \mathrm{c}$ & $2452.8 \pm 50.5 \mathrm{c}$ & $0.5 \pm 0.0 \mathrm{c}$ & $5.11 \pm 0.20 \mathrm{c}$ \\
\hline
\end{tabular}

${ }^{1}$ Mean values in the column followed by different letters are significantly different $(p<0.05$, ANOVA, Bonferroni test).

Loponen [30] suggests that the application of LAB and their enzymatic apparatus in the fermentation of bread sourdough has the potential of producing "gluten-free" or "gluten-reduced" food in conformity with the Codex Alimentarius. According to the definition, a "gluten-free" and "gluten-reduced" label may be placed on food products with gluten concentrations not exceeding $20 \mathrm{mg} / \mathrm{kg}$ and below $100 \mathrm{mg} / \mathrm{kg}$, respectively [31].

Immunochemical analyses indicated that enzymatic hydrolysis of proteins decreases the concentration of the QQPFP amino acid sequences in products, which are coeliac-toxic and detected by $\mathrm{R} 5$ antibodies. In the experiments, R5 monoclonal antibody was used, which detects (among others) QQPFP, LQLQPFP, QLPYP, PQPF and PQPFP amino acid sequences present in the primary structure of gliadins [32]. The concentration of a QQPFP is the sum of detected amino acid sequences. The concentration of a QQPFP peptide in a sample of native gliadins reached 47,689.8 $\pm 221.1 \mathrm{mg} / \mathrm{kg}$, and its specific immunoreactivity was $269,412.5 \pm 4831.0 \mu \mathrm{g} / \mathrm{mg}$ (Table 2). Gliadin hydrolysates obtained after enzymatic reaction catalysed at $37^{\circ} \mathrm{C}$ and $\mathrm{pH} 4$ were characterised by a statistically significantly $(p<0.05$, ANOVA, Bonferroni test) lower concentration of the QQPFP peptide $(432.2 \pm 4.3 \mathrm{mg} / \mathrm{kg})$ and lower specific immunoreactivity $(0.1 \pm 0.0 \mu \mathrm{g} / \mathrm{mg})$ than the other hydrolysate samples. Moreover, an enzymatic catalysis carried out at $30^{\circ} \mathrm{C}$ and $\mathrm{pH}$ 6.0, yielded the lowest degradation degree of proteins, including the coeliac-toxic QQPFP amino acid sequence, whose concentration in this sample reached 16,097.5 $\pm 118.1 \mathrm{mg} / \mathrm{kg}$. This product also exhibited the highest specific immunoreactivity, reaching $4.2 \pm 0.0 \mu \mathrm{g} / \mathrm{mg}$ (Table 2). The increase in catalysis temperature from 30 to $37^{\circ} \mathrm{C}$ reduced the concentration of QQPFP peptide in hydrolysates obtained after reactions carried out at $\mathrm{pH} 4.0$ and 6.0 by $84.8 \%$ and $77.2 \%$, respectively. The relative immunoreactivity of gliadin hydrolysates was statistically significantly $(p<0.05$, ANOVA, Bonferroni test) lower than in the native protein sample (Table 2$)$. However, products obtained after enzymatic degradation at $\mathrm{pH} 4.0$ and at the temperature of 30 and $37^{\circ} \mathrm{C}$ demonstrated the lowest immunoreactivity, reaching $4.0 \pm 0.1 \%$ and $0.9 \pm 0.0 \%$, respectively.

Previous experiments involving a reaction catalysed by peptidases synthesised by L. acidophilus $5 \mathrm{e} 2$ found the degree of hydrolysis of $17.0 \%$ and an $83.9 \%$ reduction in immunoreactivity after a $6 \mathrm{~h}$ reaction at $30{ }^{\circ} \mathrm{C}$, using an enzyme dose of $10 \mathrm{U} / \mathrm{g}$ of flour [5]. However, according to other studies, a further reduction in wheat protein immunoreactivity is only possible through the sequential action of peptidases from L. acidophilus $5 \mathrm{e} 2$ during dough processing and then, only during bread protein in vitro digestion with pepsin, trypsin, chymotrypsin and prolyl endopeptidase. Following such multistep hydrolysis, the concentration of the QQPFP immunoreactive peptide was $7.9 \mathrm{mg} / \mathrm{kg}$ [5].

Enzymatic hydrolysis of wheat flour with prolyl endopeptidase synthesised by $A$. niger resulted in a $98 \%$ reduction in gluten concentration to $5.0 \mathrm{mg} / \mathrm{kg}$ following an $8 \mathrm{~h}$ hydrolysis at $40{ }^{\circ} \mathrm{C}$ [33]. These results conform with the findings reported by Walter et al. [34], who noted a $99 \%$ reduction in the immunoreactivity of proteins in wheat bran to $15 \mathrm{mg} / \mathrm{kg}$ after a $48 \mathrm{~h}$ reaction at $50{ }^{\circ} \mathrm{C}$ catalysed 
by prolyl endopeptidase. Another study by Mohan Kumar et al. [35] found that depending on the wheat variety (Triticum aestivum (HD-2851, NIAW-917), Triticum durum (UAS-428) or Triticum dicoccum (DDK-1025)), under the same reaction conditions $\left(40^{\circ} \mathrm{C}, \mathrm{pH} 4.0\right.$ and prolyl endopeptidase dose of $4 \mathrm{U} / \mathrm{g}$ ), the gluten concentration may be reduced from $74 \%$ to $95 \%$.

Gliadins and products of their hydrolysis were separated using two-dimensional gel electrophoresis and their immunoreactive properties were then identified with R5 antibodies (Figure 1). Native gliadins comprised 35 fractions with molecular weights from 28 to $65 \mathrm{kDa}$ and isoelectric point ranging from pI 4.0 to 9.5 , including 18 immunoreactive fractions (Table 3).

A comparison of electrophoretic images of the native and hydrolysed proteins revealed that 74.3-94.3\% of the polypeptides represented the same molecular weight and isoelectric point. The other fractions (5.7-25.7\%) constituted polypeptides released from gliadins in the enzymatic degradation process. Following gliadin hydrolysis, the number of identified peptides increased from 35 for the native protein sample to 37 and 38 for the hydrolysate samples. Based on the electrophoretic images, it was further noted that depending on the reaction conditions, 5-11 polypeptides with molecular weights below $28 \mathrm{kDa}$ were released from gliadins subjected to hydrolysis. Moreover, the immunochemical analysis detected proteins capable of binding R5 antibodies in both fractions, i.e., the $28-65 \mathrm{kDa}$ fraction characteristic of native gliadins and the below $28 \mathrm{kDa}$ fraction corresponding to released peptides. However, the lowest number of immunoreactive peptide fractions (14 spots) was determined in the sample of gliadins hydrolysed at $37^{\circ} \mathrm{C}$ and $\mathrm{pH} 4.0$ (Figure 1d). The other products of hydrolysis comprised from 18 to 21 immunoreactive fractions (Table 3 ).
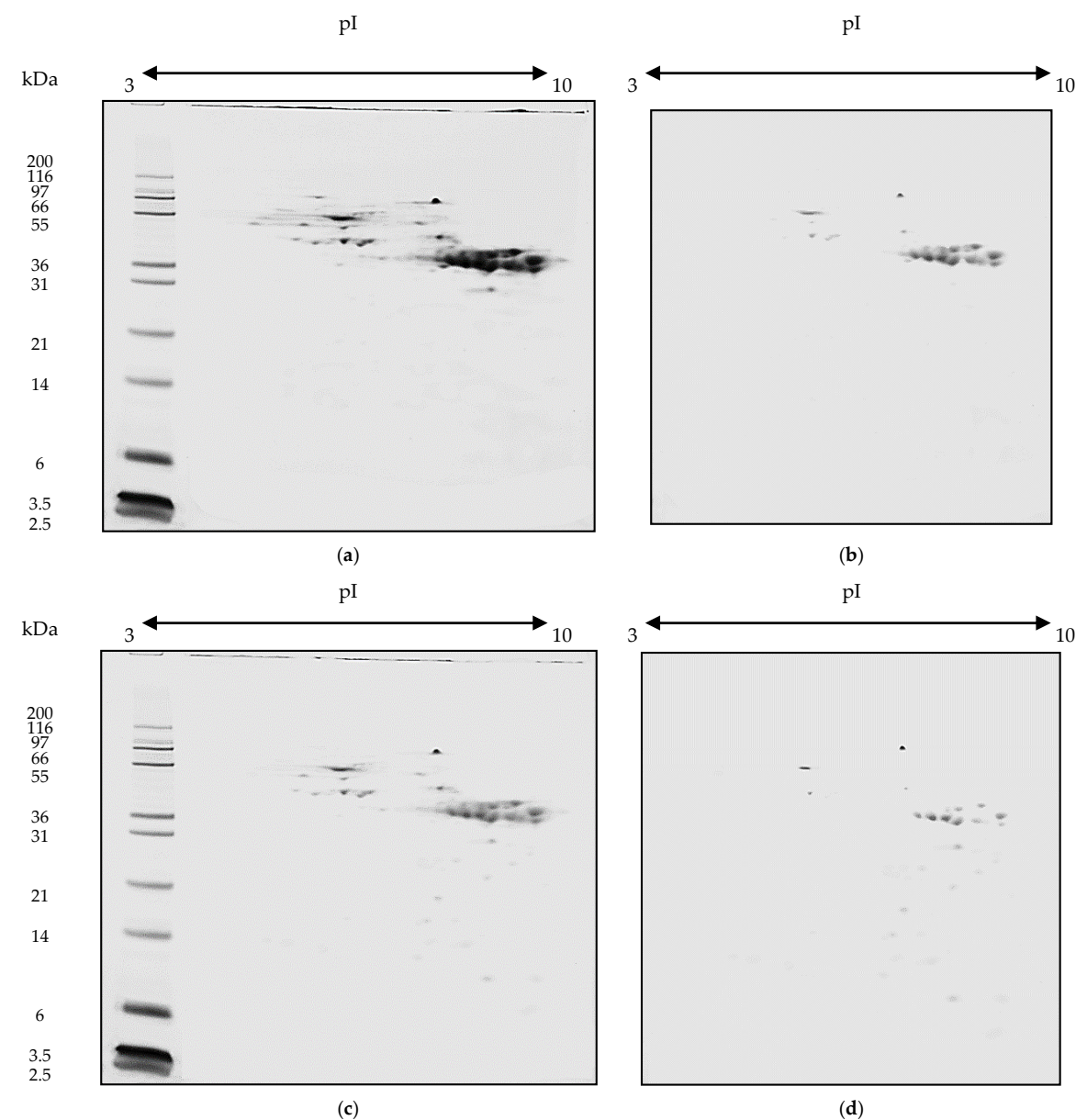

Figure 1. Electropherograms 2D NuPAGE of native gliadins (a) and gliadins hydrolysed by a mixture of peptidases from L. acidophilus $5 \mathrm{e} 2$ and A. niger (c) and immunoblots of native (b) and hydrolysed gliadins (d). Reaction conditions: $\mathrm{pH} 4,37^{\circ} \mathrm{C}, 3 \mathrm{~h}$. 
Table 3. Effect of reaction conditions on the number of spots before and after immunodetection of native gliadins (control) and products of hydrolysis by a mixture of peptidases from L. acidophilus 5e2 and $A$. niger after a $3 \mathrm{~h}$ incubation.

\begin{tabular}{cccc}
\hline Hydrolysis Parameters & $\begin{array}{c}\text { Molecular Weight of } \\
\text { Fraction (kDa) }\end{array}$ & No. of Spots & $\begin{array}{c}\text { No. of } \\
\text { Immuno-Reactive Spots }\end{array}$ \\
\hline \multirow{2}{*}{ Control } & $<28$ & 0 & 0 \\
$30^{\circ} \mathrm{C} ; \mathrm{pH} 4$ & $28-65$ & 35 & 18 \\
& $<28$ & 9 & 6 \\
$30^{\circ} \mathrm{C} ; \mathrm{pH} 6$ & $28-65$ & 28 & 12 \\
$37^{\circ} \mathrm{C} ; \mathrm{pH} 4$ & $<28$ & 5 & 4 \\
$37^{\circ} \mathrm{C} ; \mathrm{pH} 6$ & $28-65$ & 33 & 6 \\
& $28-65$ & 26 & 8 \\
& $<28$ & 8 & 5 \\
\hline
\end{tabular}

The competitive and sandwich ELISA are assays recommended by Codex Alimentarius to perform gluten concentration measurements [31]. Protein hydrolysate immunoreactivity measurements are carried out with competitive assays using R5 monoclonal antibodies, which are capable of detecting fragments of polypeptide chains (including QQPFP, QQQFP, LQPFP and QLPFP amino acid sequences), present in wheat, rye and barley prolamins recognised as toxic to coeliac patients [36].

\subsection{Hydrolysis of Coeliac-Toxic Peptides}

Peptidases synthesised by L. acidophilus $5 \mathrm{e} 2$ and prolyl endopeptidase from A. niger were used to catalyse hydrolysis of the following peptides: LGQQQPFPPQQPY (P1) and PQPQLPYPQPQLP (P2), which play an important role in coeliac pathogenesis $[13,26]$. The hydrolysis degree of peptide P1 ranged from $93.1 \pm 0.7$ to $99.8 \pm 0.0 \%$ (Table 4 ) and depended on the reaction conditions. Based on the results of the capillary electrophoresis, complete hydrolysis of peptide P1 was obtained after a reaction carried out at $\mathrm{pH} 4.0$ and $37^{\circ} \mathrm{C}$ (Figure 2). Moreover, it was noted that a decrease in both the reaction temperature and acidity, statistically significantly $(p<0.05$, ANOVA, Bonferroni test) reduced the degree of hydrolysis of the peptide by $4.3-6.9 \%$. The degree of hydrolysis of peptide P2 ranged from $89.4 \pm 0.3$ to $97.5 \pm 0.1 \%$. Similar to the experiment with peptide $\mathrm{P} 1$, the reaction mixture acidity of $\mathrm{pH} 4.0$ and the temperature of $37^{\circ} \mathrm{C}$ yielded the highest hydrolysis degree of peptide P2. Further, a decrease in the reaction temperature from 37 to $30^{\circ} \mathrm{C}$ and its acidity from $\mathrm{pH} 4.0$ to 6.0 , statistically significantly $(p<0.05$, ANOVA, Bonferroni test) reduced the hydrolysis degree by $4.4-8.1 \%$.

The immunochemical assays conducted in this study demonstrated a reduction in relative immunoreactivity of $\mathrm{P} 1$ and $\mathrm{P} 2$ peptide degradation products using peptidases from L. acidophilus 5e2 and prolyl endopeptidase from $A$. niger (Table 4). The obtained relative immunoreactivity ranged from $0.8 \pm 0.0 \%$ to $8.8 \pm 0.0 \%$ and from $3.2 \pm 0.0 \%$ to $11.5 \pm 0.0 \%$, respectively, for the P1 and P2 peptide hydrolysates, although the lowest RI values were reported for products obtained after a reaction conducted at $\mathrm{pH} 4.0$ and $37^{\circ} \mathrm{C}$. A decrease in the reaction mixture acidity from $\mathrm{pH} 4.0$ to 6.0 caused a statistically significant ( $p<0.05$, ANOVA, Bonferroni test) increase in the immunoreactivity of $\mathrm{P} 1$ peptide hydrolysates (by $18.2 \%$ and $90.9 \%$, respectively) for samples incubated at 30 and $37^{\circ} \mathrm{C}$. An increase in the reaction temperature from 30 to $37^{\circ} \mathrm{C}$ also promoted a statistically significant $(p<0.05$, ANOVA, Bonferroni test) reduction in the immunoreactivity of products obtained from P1 peptide hydrolysis (by $82.2 \%$, reaction at $\mathrm{pH} 4.0$ ), although a temperature increase resulted in a $60.0 \%$ increase in hydrolysate immunoreactivity after the reaction carried out at $\mathrm{pH}$ 6.0. Similar relationships were found in the experiment with substrate P2 where, depending on acidity of the reaction mixture, an increase in the temperature reduced or increased the hydrolysate immunoreactivity for $\mathrm{pH} 4.0$ and 6.0 , respectively. 
Table 4. Effect of reaction conditions on the degree of hydrolysis (DH, \%), concentration of QQPFP sequence $(\mathrm{C}, \mathrm{mg} / \mathrm{kg}$ ) and relative immunoreactivity (RI, \%) of hydrolysed peptides: LGQQQPFPPQQPY (P1) and PQPQLPYPQPQLP (P2) by a mixture of peptidases from L. acidophilus $5 \mathrm{e} 2$ and A. niger after $3 \mathrm{~h}$ of incubation.

\begin{tabular}{ccccccc}
\hline \multirow{2}{*}{ Hydrolysis Parameters } & \multicolumn{2}{c}{ DH (\%) } & \multicolumn{2}{c}{ C (mg/kg) } & \multicolumn{2}{c}{ RI (\%) } \\
\cline { 2 - 7 } & P1 & P2 & P1 & P2 & P1 & P2 \\
\hline Control & $0.0 \pm 0.0 \mathrm{a}^{1}$ & $0.0 \pm 0.0 \mathrm{a}$ & $403.2 \pm 0.3 \mathrm{e}$ & $401.8 \pm 0.3 \mathrm{e}$ & $100.0 \pm 0.0 \mathrm{e}$ & $100.0 \pm 0.0 \mathrm{e}$ \\
$30^{\circ} \mathrm{C} ; \mathrm{pH} 4$ & $95.7 \pm 0.6 \mathrm{c}$ & $93.1 \pm 0.6 \mathrm{~d}$ & $18.2 \pm 0.1 \mathrm{~b}$ & $23.5 \pm 0.2 \mathrm{~b}$ & $4.5 \pm 0.0 \mathrm{~b}$ & $5.9 \pm 0.0 \mathrm{~b}$ \\
$30^{\circ} \mathrm{C} ; \mathrm{pH} \mathrm{6}$ & $93.1 \pm 0.7 \mathrm{~b}$ & $91.3 \pm 0.5 \mathrm{c}$ & $22.1 \pm 0.2 \mathrm{c}$ & $36.1 \pm 0.3 \mathrm{c}$ & $5.5 \pm 0.0 \mathrm{c}$ & $9.0 \pm 0.0 \mathrm{c}$ \\
$37^{\circ} \mathrm{C} ; \mathrm{pH}$ & $99.8 \pm 0.0 \mathrm{~d}$ & $97.5 \pm 0.1 \mathrm{e}$ & $3.2 \pm 0.1 \mathrm{a}$ & $12.8 \pm 0.2 \mathrm{a}$ & $0.8 \pm 0.0 \mathrm{a}$ & $3.2 \pm 0.0 \mathrm{a}$ \\
$37^{\circ} \mathrm{C}$; pH 6 & $94.5 \pm 0.4 \mathrm{c}$ & $89.4 \pm 0.3 \mathrm{~b}$ & $35.3 \pm 0.1 \mathrm{~d}$ & $46.2 \pm 0.2 \mathrm{~d}$ & $8.8 \pm 0.0 \mathrm{~d}$ & $11.5 \pm 0.0 \mathrm{~d}$ \\
\hline
\end{tabular}

${ }^{1}$ Mean values in the column followed by different letters are significantly different $(p<0.05$, ANOVA, Bonferroni test).

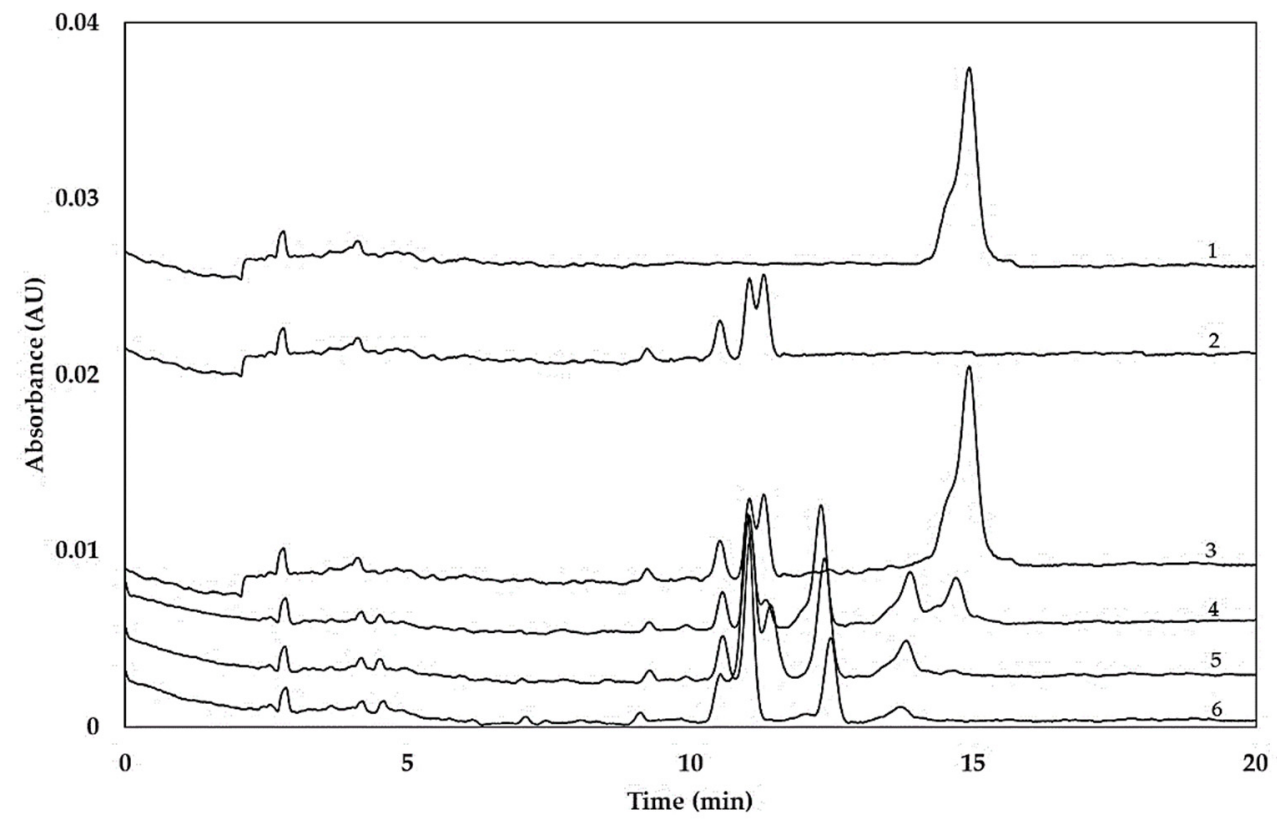

Figure 2. Electropherograms (FZCE) of peptide LGQQQPFPPQQPY (1), mixture of peptidases from L. acidophilus 5e2 and A. niger (2) and products obtained after 0 (3), 1 (4), 2 (5) and $3 \mathrm{~h} \mathrm{(6)} \mathrm{of} \mathrm{incubation}$ at $37^{\circ} \mathrm{C}$ and $\mathrm{pH} 4.0$.

De Angelis et al. [20] also confirm the capability of a mixture of proteolytic enzymes synthesised by L. sanfranciscensis 7A, LS3, LS10, LS19, LS23, LS38, LS47, L. alimentarius 15M, L. brevis 14G and L. hilgardii 51B, as well as $A$. oryzae and $A$. niger, to hydrolyse gliadins. The application of a mixture of bacterial and fungal peptidases at the dose of $1 \mu \mathrm{g} / \mathrm{cm}^{3}$, equivalent of approximately $3 \times 10^{9} \mathrm{cfu} / \mathrm{g}$, decreased the gluten concentration to a safe level of below $2 \mathrm{mg} / \mathrm{kg}$ in $72 \mathrm{~h}$ at $37^{\circ} \mathrm{C}$. The same peptidase mixture also effectively degraded a 33-mer oligopeptide involved in coeliac disease pathogenesis and resistant to digestion by the human gastrointestinal tract. Moreover, the same research team reported that wheat flour protein hydrolysis carried out at $37^{\circ} \mathrm{C}$ for $48 \mathrm{~h}$ by LAB from bread sourdough in the combination with fungal peptidases produced bread safe for gluten-sensitive consumers [24]. However, such a process offers limited application due to its time-consuming fermentation. Therefore, the application of a mixture of LAB and fungal peptidases in catalysis of wheat protein hydrolysis seems to be promising. LAB synthesise a mixture of peptidases characterised by a wide spectrum of activity and specificity towards amino acid residues in a polypeptide chain, while prolyl endopeptidase from $A$. niger hydrolyses mainly peptide bonds formed by proline residues [21,29].

The amino acid sequences of both peptides used in the present experiment comprise the QQPFP motif. The application of a mixture of peptidases from L. acidophilus $5 \mathrm{e} 2$ and prolyl endopeptidase decreased the concentration of QQPFP in the hydrolysates of coeliac-toxic peptides. The initial 
concentration $(403.2 \pm 0.3 \mathrm{mg} / \mathrm{kg})$ of a LGQQQPFPPQQPY peptide was reduced and, depending on the reaction conditions, it ranged from $3.2 \pm 0.1$ to $35.3 \pm 0.1 \mathrm{mg} / \mathrm{kg}$ (Table 4). Finally, the highest reduction in the concentration of the QQPFP sequence (by $99.2 \%$ ) was noted following hydrolytic catalysis carried out at $\mathrm{pH} 4.0$ and $37^{\circ} \mathrm{C}$, while the lowest (by $91.2 \%$ ) was observed in the fermentation conducted at $\mathrm{pH} 6.0$ and $30^{\circ} \mathrm{C}$. Hydrolysates of $\mathrm{P} 2$ peptide were also characterised by a lower concentration of QQPFP sequence, ranging from $12.8 \pm 0.2$ to $46.2 \pm 0.2 \mathrm{mg} / \mathrm{kg}$, compared with the native peptide $(401.8 \pm 0.3 \mathrm{mg} / \mathrm{kg})$. The lowest concentration of QQPFP sequence of $12.8 \pm 0.2 \mathrm{mg} / \mathrm{kg}$ was noted following P2 peptide hydrolysis conducted at $\mathrm{pH} 4.0$ and $37^{\circ} \mathrm{C}$.

In the commonly used bread-making technology, the time-consuming fermentation with sourdough comprising $\mathrm{LAB}$, the source of $L$. acidophilus $5 \mathrm{e} 2$, responsible for dough acidification and proteolysis, has been superseded by short processes with the application of various bread additives. Such technology does not ensure the degradation of cereal proteins. However, bread technology can be successfully modified to offer effective degradation of immunoreactive wheat proteins in a shorter time than in traditional processes, by an in situ application of LAB and fungal peptidase combinations.

\section{Materials and Methods}

\subsection{Materials}

Analyses were carried out on wheat grain samples of the Nawra hexaploid cultivar (Triticum aestivum L., glutenin allele N-7+8-5+10) obtained from the Experimental Station in Bałcyny, University of Warmia and Mazury in Olsztyn. The L. acidophilus 5e2 strain of LAB was provided by the Department of Food Biotechnology (University of Warmia and Mazury in Olsztyn, Poland) and was stored at $-35^{\circ} \mathrm{C}$ in MRS-broth (Merck, Darmstadt, Germany) with the addition of glycerol $(25 \%, v / v)$. Before the experiment, the bacteria were double-passaged on MRS-broth and incubated for $12 \mathrm{~h}$ at $37^{\circ} \mathrm{C}$. Prolyl endopeptidase (Brewers Clarex) synthesised by Aspergillus niger was provided by DSM Food Specialties (Mszczonów, Poland). All chemical reagents were supplied by Sigma-Aldrich (Poznań, Poland).

\subsection{Biosynthesis and Isolation of Peptidases}

A sterile MRS-broth $\left(1800 \mathrm{~cm}^{3}\right)$ supplemented with gluten $(10 \%, w / v$, Sigma G5004) was inoculated with a $12 \mathrm{~h}$ culture of L. acidophilus $5 \mathrm{e} 2$ bacteria $(10 \%, v / v)$ and a stationary culture was run without aeration at $37^{\circ} \mathrm{C}$ for $24 \mathrm{~h}$. The LAB biomass was separated from the postculture liquid by centrifugation $\left(5000 \mathrm{~g}, 20 \mathrm{~min}, 5^{\circ} \mathrm{C}\right)$ and double-rinsed with a sterile saline solution $\left(20 \mathrm{~cm}^{3}, \mathrm{NaCl}, 8 \mathrm{~g} / \mathrm{dm}^{3}\right)$, each time separating the biomass by centrifugation. The biomass was then suspended $(10 \%, w / v)$ in a sterile saline solution and sonicated (pulse on: $4 \mathrm{~s}$; pulse off: $1 \mathrm{~s} ; 5^{\circ} \mathrm{C}, 30 \mathrm{~min}$; VCX500 Vibra-Cell, Sonics, Newtown, CT, USA). A homogenate containing intracellular and cell wall-attached peptidases was frozen and freeze-dried $\left(-60^{\circ} \mathrm{C}, 0.5 \mathrm{~Pa}, 24 \mathrm{~h}\right)$.

\subsection{Determination of the Enzyme Preparation Activity}

The activity assays of peptidases obtained from the L. acidophilus 5e 2 culture and prolyl endopeptidase from Aspergillus niger were performed as described earlier [10].

\subsection{Gliadin Isolation}

Grain samples (100 g) were milled, suspended in a buffer $\left(300 \mathrm{~cm}^{3}, 50 \mathrm{mmol} / \mathrm{dm}^{3}\right.$ Tris-HCl pH 7.8 ; $\left.100 \mathrm{mmol} / \mathrm{dm}^{3} \mathrm{KCl}, 5 \mathrm{mmol} / \mathrm{dm}^{3} \mathrm{EDTA}\right)$, mixed $\left(5 \mathrm{~min}, 21^{\circ} \mathrm{C}\right)$ and centrifuged $\left(8000 \mathrm{~g}, 15 \mathrm{~min}, 21^{\circ} \mathrm{C}\right)$ to remove albumins and globulins. Proteins soluble in buffered salt solutions were extracted twice. The grain samples were then washed twice with deionised water $\left(300 \mathrm{~cm}^{3}\right)$, mixed $\left(5 \mathrm{~min}, 21^{\circ} \mathrm{C}\right)$ and centrifuged to remove precipitate $\left(2000 \mathrm{~g}, 15 \mathrm{~min}, 21^{\circ} \mathrm{C}\right)$. Gliadins were extracted $\left(30 \mathrm{~min}, 21^{\circ} \mathrm{C}\right)$ from samples with ethanol solution $\left(300 \mathrm{~cm}^{3}, 60 \%, v / v\right)$ and separated by centrifugation $(10,000 \mathrm{~g}$, 
$\left.15 \mathrm{~min}, 21^{\circ} \mathrm{C}\right)$. The ethanol was evaporated $\left(50^{\circ} \mathrm{C}, 0.01 \mathrm{MPa}\right)$ and the gliadin solution was frozen and freeze-dried $\left(-60^{\circ} \mathrm{C}, 1.1 \mathrm{~Pa}, 24 \mathrm{~h}\right)$.

\subsection{Gliadin Hydrolysis}

Enzymatic hydrolysis of gliadins was performed at 30 or $37^{\circ} \mathrm{C}$ in $\mathrm{pH} 4.0$ or 6.0 for $3 \mathrm{~h}$ using $100 \mathrm{U}$ of enzyme per mg of gliadin ( $50 \mathrm{U}$ of peptidases from L. acidophilus $5 \mathrm{e} 2$ and $50 \mathrm{U}$ of prolyl endopeptidase from A. niger). The addition of peptidases synthesised by L. acidophilus $5 \mathrm{e} 2$ was determined based on the activity of endopeptidases.

The substrate $\left(1 \mathrm{~g}\right.$, gliadins) was suspended in $30 \mathrm{~cm}^{3}$ of phosphate buffer with ethanol $\left(0.2 \mathrm{mmol} / \mathrm{dm}^{3} \mathrm{Na}_{2} \mathrm{HPO}_{4} / \mathrm{H}_{3} \mathrm{PO}_{4}\right.$ buffer, $\mathrm{pH} 4.0$ and $6.0 ; 30 \%$ ethanol, $\left.v / v\right)$ containing a mixture of peptidase preparation from L. acidophilus $5 \mathrm{e} 2$ and $A$. niger and subjected to hydrolysis $(3 \mathrm{~h}, 30$ and $\left.37^{\circ} \mathrm{C}, 100 \mathrm{rpm}\right)$. Products of hydrolysed gliadins were heat-treated $\left(15 \mathrm{~min}, 95^{\circ} \mathrm{C}\right)$ to inactivate enzymes.

The 2D-electrophoresis with immunoblotting was performed and the protein hydrolysis degree and immunoreactivity were determined for the substrate (control) and the hydrolysed gliadins.

\subsection{Peptide Hydrolysis}

A mixture of peptidases from L. acidophilus $5 \mathrm{e} 2$ and A. niger was used for hydrolysis of two substrates: LGQQQPFPPQQPY and PQPQLPYPQPQLP (JPT Peptide Technologies GmbH, Berlin, Germany) important in coeliac pathogenesis $[13,26]$.

Each of the peptides was suspended in a phosphate buffer $\left(1 \mathrm{mg} / \mathrm{cm}^{3}, 20 \mathrm{mmol} / \mathrm{dm}^{3}\right.$ $\mathrm{Na}_{2} \mathrm{HPO}_{4} / \mathrm{H}_{3} \mathrm{PO}_{4}$ buffer, $\mathrm{pH} 4.0$ and 6.0) containing a mixture of peptidase preparations from L. acidophilus $5 \mathrm{e} 2$ and $A$. niger (50 and $50 \mathrm{U}$ per mg of peptide, respectively) and incubated ( $3 \mathrm{~h}$, 30 and $\left.37^{\circ} \mathrm{C}\right)$. Samples of the hydrolysed peptide $\left(0.05 \mathrm{~cm}^{3}\right)$ were collected every hour, heat treated $\left(15 \mathrm{~min}, 95^{\circ} \mathrm{C}\right)$ to inactivate enzymes and analysed by free-zone capillary electrophoresis. The residue sample was incubated for $3 \mathrm{~h}$, frozen and freeze-dried $\left(-60^{\circ} \mathrm{C}, 1.1 \mathrm{~Pa}, 24 \mathrm{~h}\right)$. Protein immunoreactivity was determined for peptides and hydrolysed peptides.

\subsection{D-NuPAGE Electrophoresis and Immunoblotting of Gliadins}

\subsubsection{Sample Preparation}

Samples of native and hydrolysed gliadins $(100 \mathrm{mg})$ were suspended in a mixture of acetone $\left(1 \mathrm{~cm}^{3}\right)$, trichloroacetic acid $(10 \%, w / v)$ and $\beta$-mercaptoethanol $(0.07 \%, v / v)$, mixed thoroughly and then incubated $\left(-30^{\circ} \mathrm{C}, 2 \mathrm{~h}\right)$. Precipitated proteins were separated from the mixture by centrifuging $\left(10,000 \mathrm{~g}, 20^{\prime} \mathrm{min}, 5^{\circ} \mathrm{C}\right)$, suspended in a mixture of acetone $\left(1 \mathrm{~cm}^{3}\right)$ and $\beta$-mercaptoethanol $(0.07 \%, v / v)$ and mixed. The mixture was centrifuged again $\left(10,000 \mathrm{~g}, 20 \mathrm{~min}, 5^{\circ} \mathrm{C}\right)$ to obtain protein precipitate. The acetone mixture was evaporated in a vacuum evaporator $\left(30^{\circ} \mathrm{C}, 0.055 \mathrm{MPa}\right)$.

Proteins were suspended in a buffer $\left(0.95 \mathrm{~cm}^{3}\right)$ containing ZOOM 2D Protein Solubiliser 1 $\left(0.914 \mathrm{~cm}^{3}, 2 \mathrm{DPS} 1\right.$, Invitrogen, Thermo Fisher Scientific, Waltham, MA, USA), Tris $\left(0.003 \mathrm{~cm}^{3}\right.$, $\left.1 \mathrm{~mol} / \mathrm{dm}^{3}\right)$, a mixture of protease inhibitors $\left(0.005 \mathrm{~cm}^{3}\right.$, Sigma P9599), dithiothreitol $\left(0.01 \mathrm{~cm}^{3}\right.$, $\left.2 \mathrm{~mol} / \mathrm{dm}^{3}, \mathrm{DTT}\right)$ and deionised water $\left(0.018 \mathrm{~cm}^{3}\right)$ and mixed for $15 \mathrm{~min}$ according to the manufacturer's instructions. N, N-dimethylacrylamide $\left(0.005 \mathrm{~cm}^{3}, \mathrm{DMA}\right)$ was then added to alkylate proteins and the sample was mixed for $30 \mathrm{~min}$. The process was terminated by adding DTT $\left(0.01 \mathrm{~cm}^{3}, 2 \mathrm{~mol} / \mathrm{dm}^{3}\right)$. Dissolved protein fractions were separated from the precipitate by centrifuging $\left(20,000 \mathrm{~g}, 20 \mathrm{~min}, 5^{\circ} \mathrm{C}\right)$ and were then frozen $\left(-30^{\circ} \mathrm{C}\right)$.

\subsubsection{Isoelectric Focusing of Proteins}

Protein isoelectric focusing was performed according to Akagawa et al. [37] with slight modifications. Protein samples $\left(0.010 \mathrm{~cm}^{3}\right)$ were suspended in a buffer containing 2DPS1 solubiliser $\left(0.128 \mathrm{~cm}^{3}\right.$, Invitrogen), DTT $\left(0.0007 \mathrm{~cm}^{3}, 2 \mathrm{~mol} / \mathrm{dm}^{3}\right)$, a mixture of ampholytes $\left(0.001 \mathrm{~cm}^{3}, \mathrm{ZOOM}\right.$ Carrier Ampholytes, Invitrogen), Bromophenol Blue $\left(0.0003 \mathrm{~cm}^{3}, 1 \%, w / v\right)$ and deionised water 
$\left(0.146 \mathrm{~cm}^{3}\right)$. The whole sample was mixed and applied onto a gel strip for rehydration $\left(12 \mathrm{~h}, 21^{\circ} \mathrm{C}\right)$ and isoelectric focusing (linear gradient pH 3-10 L, Invitrogen). Gel strips were placed inside a ZOOM IPGRunner apparatus (Invitrogen), and isoelectric focusing was performed at room temperature at the following parameters: $175 \mathrm{~V}$ for $15 \mathrm{~min}, 175 \mathrm{~V}$ up to $2 \mathrm{kV}$ for $45 \mathrm{~min}$ and $2 \mathrm{kV}$ for $30 \mathrm{~min}$.

\subsubsection{Separation of Proteins in NuPAGE Gel}

Following isoelectric focusing of proteins, gel strips were buffered $\left(15 \mathrm{~min}, 21^{\circ} \mathrm{C}\right)$ in a sample buffer $\left(10 \mathrm{~cm}^{3}\right.$, LDS Sample Buffer with Sample Reducing Agent, 9:1, v:v, Invitrogen) and an alkylating mixture $\left(10 \mathrm{~cm}^{3}\right.$, LDS Sample Buffer, Invitrogen; $125 \mathrm{mmol} / \mathrm{dm}^{3}$ iodoacetamide, $\left.15 \mathrm{~min}, 2{ }^{\circ} \mathrm{C}\right)$. Next, the strips were applied onto polyacrylamide gel (NuPAGE Novex 4-12\% Bis-Tris ZOOM Gels, IPG Well $1.0 \mathrm{~mm}$, Invitrogen) and poured over with agarose solution $\left(0.5 \mathrm{~cm}^{3}, 0.5 \%, w / v\right)$. Proteins were separated in an electrophoretic apparatus (XCell6 MultiGel Unit, Invitrogen) using a protein separation buffer (NuPAGE SDS MES, Invitrogen) at room temperature, at $200 \mathrm{~V}$ for $40 \mathrm{~min}$. Proteins of molecular weights from 2.5 to $200 \mathrm{kDa}$ (Mark12, Invitrogen) were used as mass standards. Gels were stained with SimplyBlue SafeStain (Invitrogen) according to the manufacturer's instructions. Electropherograms were analysed with Molecular Imaging Software (Kodak, version 4.0) and Phoretix 2D (Nonlinear Dynamics Ltd., version 2004-1440-1).

\subsection{Immunoblotting}

The second gel was used for immunoblotting analysis. The separated proteins were transferred from the polyacrylamide gel onto a polyvinylidene difluoride membrane (PVDF, Invitrogen) in a XCell II Blot Module (Invitrogen). The electrotransfer was conducted in a NuPAGE transfer buffer (Invitrogen) with methanol $\left(0.025 \mathrm{~mol} / \mathrm{dm}^{3}\right.$ Bicine, $0.025 \mathrm{~mol} / \mathrm{dm}^{3}$ bis-Tris, $1 \mathrm{mmol} / \mathrm{dm}^{3}$ EDTA, $20 \%$ methanol, $v / v$, $\mathrm{pH}$ 7.2), applying $30 \mathrm{~V}$ and $170 \mathrm{~mA}$, for $1 \mathrm{~h}$. PVDF membrane was incubated overnight in a buffer $\left(0.05 \mathrm{~mol} / \mathrm{dm}^{3}\right.$ Tris-HCl, $\left.0.5 \mathrm{~mol} / \mathrm{dm}^{3} \mathrm{NaCl}, \mathrm{pH} 7.0\right)$ containing bovine serum albumin $(5 \%, w / v)$ to block free site-binding proteins and washed on the next day with TBS buffer three times for $15 \mathrm{~min}$. The PVDF membrane was incubated in TBS buffer containing an antigliadin antibody conjugated to peroxidase $\left(0.1 \% / v / v, \mathrm{~A} 1052\right.$, Sigma) and shaken $\left(2 \mathrm{~h}, 21^{\circ} \mathrm{C}\right)$. The membrane was rinsed in TBS buffer three times for $5 \mathrm{~min}$ and placed in 1-Step Ultra TMB-Blotting Solution $\left(10 \mathrm{~cm}^{3}\right.$, Thermo Scientific 37574). The colour development was stopped after $5 \mathrm{~min}$ by rinsing the membrane with water.

\subsection{Degree of Protein Hydrolysis}

The degree of hydrolysis (DH) of gliadins was determined using the o-phthaldialdehyde (OPA) method. Control and hydrolysed samples of gliadins $(100 \mathrm{mg})$ were suspended in borate buffer $\left(1 \mathrm{~cm}^{3}\right.$, $125 \mathrm{~mol} / \mathrm{dm}^{3}, \mathrm{Na}_{2} \mathrm{~B}_{4} \mathrm{O}_{7} \cdot 10 \mathrm{H}_{2} \mathrm{O}, \mathrm{H}_{3} \mathrm{BO}_{3}, \mathrm{pH} 8.5$ ) with sodium dodecyl sulphate (SDS, $2 \%$, w/v), mixed $\left(30 \mathrm{~min}, 21^{\circ} \mathrm{C}, 100 \mathrm{rpm}\right)$ and centrifuged $\left(5000 \mathrm{~g}, 10 \mathrm{~min}, 21^{\circ} \mathrm{C}\right)$. Supernatants $\left(0.125 \mathrm{~cm}^{3}\right)$ were mixed with an OPA reagent $\left(5 \mathrm{~cm}^{3}\right)$ composed of $o$-phthaldialdehyde $(0.08 \%, w / v)$, methanol $(2 \%, v / v)$ and 2-mercaptoethanol $(0.2 \%, v / v)$ filled up to $1 \mathrm{dm}^{3}$ with borax solution $\left(0.1 \mathrm{~mol} / \mathrm{dm}^{3}, \mathrm{Na}_{2} \mathrm{~B}_{4} \mathrm{O}_{7} \cdot 10 \mathrm{H}_{2} \mathrm{O}\right)$. The mixture was allowed to stand for $20 \mathrm{~min}$ before measurement of the absorbance at a wavelength of $340 \mathrm{~nm}$ (Multiskan GO, Thermo Scientific, Waltham, MA, USA). The number of amino groups was determined based on the L-leucine standard curve between $1.25 \times 10^{-6}$ and $1.0 \times 10^{-5} \mathrm{mmol} / \mathrm{dm}^{3}$. The changes in $\alpha$-amino groups between control and hydrolysed samples were attributed to proteolysis and the degree of hydrolysis (DH) was calculated by the following equation:

$$
\mathrm{DH}(\%)=\left(\alpha-\mathrm{n}_{\mathrm{i}}\right) / \mathrm{n}_{\mathrm{T}} \cdot 100 \%,
$$

where $\mathrm{n}_{T}$ was the total number of amino groups in native gliadins after acid hydrolysis, $\mathrm{n}_{\mathrm{i}}$ was the number of amino groups in control samples and $\alpha$ was the number of free amino groups in the hydrolysed gliadins. 
The total number of amino groups in gliadin was determined after acid hydrolysis. The samples of gliadins $(100 \mathrm{mg})$ were suspended in $\mathrm{HCl}$ solution $\left(5 \mathrm{~cm}^{3}, 6 \mathrm{~mol} / \mathrm{dm}^{3}\right)$, sealed in a glass ampule and then incubated $\left(24 \mathrm{~h}, 105^{\circ} \mathrm{C}\right)$. Hydrolysed gliadins were neutralised with $\mathrm{NaOH}$ solution $\left(5 \mathrm{~cm}^{3}\right.$, $6 \mathrm{~mol} / \mathrm{dm}^{3}$ ) and centrifuged $\left(5000 \mathrm{~g}, 10 \mathrm{~min}, 21^{\circ} \mathrm{C}\right)$. The total number of amino groups in gliadins was determined with the OPA method.

\subsection{Free Zone Capillary Electrophoresis of Peptides}

Samples of native and hydrolysed peptides were analysed using a system for capillary electrophoresis (BioFocus 3000, Bio-Rad, Hercules, CA, USA) according to the method of Lookhart and Bean [38]. All chemical reagents and buffers were degassed by centrifuging $(10,000 \mathrm{~g}, 2 \mathrm{~min}$, $21^{\circ} \mathrm{C}$ ) before they were used in electrophoretic separation. Hydrolysed peptides were separated in phosphate buffer $\left(0.1 \mathrm{~mol} / \mathrm{dm}^{3} \mathrm{NaH}_{2} \mathrm{PO}_{4} / \mathrm{H}_{3} \mathrm{PO}_{4}, \mathrm{pH} 2.65 ; 0.05 \%\right.$ hydroxypropyl-methylcellulose, $\left.w / v\right)$ at a voltage of $12.5 \mathrm{kV}$ at $25^{\circ} \mathrm{C}$ for $20 \mathrm{~min}$. Peptide samples were electrophoretically injected into the capillary $(10 \mathrm{kV}, 10 \mathrm{~s})$ and analysed at a wavelength of $200 \mathrm{~nm}$ using the UV-visible detector. A silica capillary with an effective length of $24 \mathrm{~cm}$ and $50 \mu \mathrm{m}$ in diameter was used for the electrophoretic separation of peptides. The qualitative and quantitative composition of proteins was analysed based on peak migration times using BioFocus Integrator software (Bio-Rad). The degrees of hydrolysis $(\mathrm{DH}, \%)$ of peptides were measured as the area (AU.s) under the electropherograms and calculated as the percentage of native peptides.

\subsection{Protein Immunoreactivity}

The samples of native and hydrolysed gliadins $(50 \mathrm{mg})$ and peptides $(0.5 \mathrm{mg})$ were extracted by stirring $\left(30 \mathrm{~min}, 21^{\circ} \mathrm{C}\right)$ with aqueous ethanol $\left(0.5 \mathrm{~cm}^{3}, 60 \%, v / v\right)$ and centrifuged $\left(5000 \mathrm{~g}, 10 \mathrm{~min}, 21^{\circ} \mathrm{C}\right)$. The supernatant, containing alcohol-soluble proteins, was analysed using RIDASCREEN Gliadin Competitive kit (R7021, R-Biopharm AG) with R5 monoclonal antibody recognising a potentially toxic QQPFP sequence and homologous sequences such as LQLQPFP, QLPYP, PQPF and PQPFP.

The immunoreactivity level of enzyme-treated gliadins or peptides was estimated in the form of two indicators: effective immunoreactivity (EI) and relative immunoreactivity (RI). EI was obtained from the following formula:

$$
\mathrm{EI}(\mu \mathrm{g} / \mathrm{mg})=\mathrm{C} / \alpha,
$$

where $C$ was the concentration of QQPFP toxic peptide ( $\mu \mathrm{g} / \mathrm{g}$ of sample) and $\alpha$ was the concentration of free amino groups in control and hydrolysed gliadins (mg L-leucine per $\mathrm{g}$ of sample).

Relative immunoreactivity level (RI) of enzyme-treated proteins was obtained from the following formula:

$$
\mathrm{RI}(\%)=\mathrm{EI}_{\mathrm{m}} / \mathrm{EI}_{0} \times 100 \% \text {, }
$$

where $\mathrm{EI}_{\mathrm{m}}$ was the effective immunoreactivity of the hydrolysed gliadins or peptides and $\mathrm{EI}_{0}$ was the effective immunoreactivity of the native gliadins or peptides expressed as the content of QQPFP toxic peptide (mg/g of sample).

\subsection{Statistical Analysis}

The presented results are the mean values \pm standard deviation of three assays from two independent experiments. Data were compared by ANOVA and Bonferroni test. The statistical significance $(p<0.05)$ was determined by using TIBCO Statistica software (ver. 13.3, TIBCO Software Inc., Palo Alto, CA, USA).

\section{Conclusions}

The results of the present experiment indicate that the studied peptidase mixture can be successfully used in the hydrolysis of HMW substrates such as gliadins and LMW peptides, which play a key role in the pathogenesis of coeliac disease. Even at a high concentration of gliadins $(432.2 \pm 4.3 \mathrm{mg} / \mathrm{kg})$, 
the effective immunoreactivity of the obtained hydrolysates was low and reached $0.08 \pm 0.00 \mu \mathrm{g} / \mathrm{mg}$. The experimental mixture of peptidases from L. acidophilus $5 \mathrm{e} 2$ and prolyl endopeptidase effectively hydrolysed both gliadins and coeliac-toxic peptides. Following a $3 \mathrm{~h}$ incubation at $\mathrm{pH} 4.0$ and $37^{\circ} \mathrm{C}$, the concentration of LGQQQPFPPQQPY and PQPQLPYPQPQLP decreased 126- and 31-fold, respectively. The mixture of peptidases from L. acidophilus $5 \mathrm{e} 2$ and A. niger is capable of performing a relatively quick degradation of proteins and peptides in a conventional fermentation and makes this process attractive for application in food biotechnology.

Author Contributions: Conceptualisation, B.B.; methodology, B.B.; validation, B.B. and M.A.; formal analysis, B.B., M.O. and K.S.; writing — original draft preparation, B.B.; writing—review and editing, M.A.; visualisation, B.B. All authors have read and agreed to the published version of the manuscript.

Funding: This project was financially supported by the Minister of Science and Higher Education as a part of the program entitled "Regional Initiative of Excellence" for the years 2019-2022, Project No. 010/RID/2018/19.

Conflicts of Interest: The authors declare no conflicts of interest.

\section{References}

1. Di Sabatino, A.; Corazza, G.R. Coeliac disease. Lancet 2009, 373, 1480-1493. [CrossRef]

2. Gilissen, L.J.W.J.; van der Meer, I.M.; Smulders, M.J.M. Reducing the incidence of allergy and intolerance to cereals. J. Cereal Sci. 2014, 59, 337-353.

3. Wieser, H. Chemistry of gluten proteins. Food Microbiol. 2007, 24, 115-119. [CrossRef] [PubMed]

4. Wieser, H.; Koehler, P. The biochemical basis of coeliac disease. Cereal Chem. 2008, 85, 1-13.

5. Brzozowski, B. Impact of food processing and simulated gastrointestinal digestion on gliadin immunoreactivity in rolls. J. Sci. Food Agric. 2018, 987, 3363-3375. [CrossRef]

6. Gass, J.; Bethune, M.T.; Siegel, M.; Spencer, A.; Khosla, C. Combination enzyme therapy for gastric digestion of dietary gluten in patients with coeliac sprue. Gastroenterology 2007, 133, 472-480. [CrossRef]

7. Gerez, C.L.; Dallagnol, A.; Rollán, G.; de Valdez, G.F. A combination of two lactic acid bacteria improves the hydrolysis of gliadin during wheat dough fermentation. Food Microbiol. 2012, 32, 427-430. [CrossRef]

8. Rizzello, C.G.; Curiel, J.A.; Nionelli, L.; Vincentini, O.; Di Cagno, R.; Silano, M.; Gobbetti, M.; Coda, R. Use of fungal proteases and selected sourdough lactic acid bacteria for making wheat bread with an intermediate content of gluten. Food Microbiol. 2014, 37, 59-68. [CrossRef]

9. Tack, G.J.; van de Water, J.M.; Bruins, M.J.; Kooy-Winkelaar, E.M.; van Bergen, J.; Bonnet, P.; Vreugdenhil, A.C.; Korponay-Szabo, I.; Edens, L.; von Blomberg, B.M.; et al. Consumption of gluten with gluten-degrading enzyme by coeliac patients: A pilot-study. World J. Gastroenterol. 2013, 19, 5837-5847. [CrossRef]

10. Brzozowski, B. Immunoreactivity of wheat proteins modified by hydrolysis and polymerisation. Eur. Food Res. Technol. 2016, 242, 1025-1040. [CrossRef]

11. Buddrick, O.; Cornell, H.J.; Small, D.M. Reduction of toxic gliadin content of wholegrain bread by the enzyme caricain. Food Chem. 2015, 170, 343-347. [PubMed]

12. Schwalb, T.; Wieser, H.; Koehler, P. Studies on the gluten-specific peptidase activity of germinated grains from different cereal species and cultivars. Eur. Food Res. Technol. 2012, 235, 1161-1170. [CrossRef]

13. Shan, L.; Marti, T.; Sollid, L.M.; Gray, G.M.; Khosla, C. Comparative biochemical analysis of three bacterial prolyl endopeptidases: Implication for coeliac sprue. Biochem. J. 2004, 383, 311-318. [CrossRef] [PubMed]

14. Wei, G.; Tian, N.; Valery, A.C.; Zhong, Y.; Schuppan, D.; Helmerhorst, E.J. Identification of pseudolysin (lasB) as an aciduric gluten-degrading enzyme with high therapeutic potential for coeliac disease. Am. J. Gastroenterol. 2015, 110, 899-908. [CrossRef]

15. Gänzle, M.; Loponen, J.; Gobbetti, M. Proteolysis in sourdough fermentations: Mechanisms and potential for improved bread quality. Trends Food Sci. Technol. 2008, 19, 513-521. [CrossRef]

16. Vermeulen, N.; Pavlovic, M.; Ehrmann, M.A.; Gänzle, M.G.; Vogel, R.F. Functional characterization of the proteolytic system of Lactobacillus sanfranciscensis DSM $20451^{\mathrm{T}}$ during growth in sourdough. Appl. Environ. Microb. 2005, 71, 6260-6266.

17. Thiele, C.; Gänzle, M.G.; Vogel, R.F. Fluorescence labelling of wheat proteins for determination of gluten hydrolysis and depolymerization during dough processing and sourdough fermentation. J. Agric. Food Chem. 2003, 51, 2745-2752. [CrossRef] 
18. De Angelis, M.; Coda, R.; Silano, M.; Minervini, F.; Rizzello, C.G.; Di Cagno, R.; Vicentini, O.; De Vincenzi, M.; Gobbetti, M. Fermentation by selected sourdough lactic acid bacteria to decrease coeliac intolerance to rye flour. J. Cereal Sci. 2006, 43, 301-314.

19. Rizzello, C.G.; Nionelli, L.; Coda, R.; De Angelis, M.; Gobbetti, M. Effect of sourdough fermentation on stabilisation, and chemical and nutritional characteristics of wheat germ. Food Chem. 2010, 119, 1079-1089. [CrossRef]

20. De Angelis, M.; Cassone, A.; Rizzello, C.G.; Gagliardi, F.; Minervini, F.; Calasso, M.; Di Cagno, R.; Francavilla, R.; Gobbetti, M. Mechanism of degradation of immunogenic gluten epitopes from Triticum turgidum L. var. durum by sourdough lactobacilli and fungal proteases. Appl. Environ. Microb. 2010, 76, 508-518. [CrossRef]

21. Di Cagno, R.; De Angelis, M.; Auricchio, S.; Greco, L.; Clarke, C.; De Vincenzi, M.; Giovannini, C.; D'Archivio, M.; Landolfo, F.; Parrilli, G.; et al. Sourdough bread made from wheat and nontoxic flours and started with selected lactobacilli is tolerated in coeliac sprue patients. Appl. Environ. Microb. 2004, 70, 1088-1096.

22. Knorr, V.; Kerpes, R.; Wieser, H.; Zarnkow, M.; Becker, T.; Koehler, P. Production and application of barley malt extract with high peptidase activity for the degradation of gluten in wort. Eur. Food Res. Technol. 2016, 242, 585-597. [CrossRef]

23. Rizzello, C.G.; Angelis, M.D.; Cagno, R.D.; Camarca, A.; Silano, M.; Losito, I.; De Vincenzi, M.; De Bari, M.D.; Palmisano, F.; Maurano, F.; et al. Highly efficient gluten degradation by lactobacilli and fungal proteases during food processing: New perspectives for coeliac disease. Appl. Environ. Microb. 2007, 73, 4499-4507.

24. Greco, L.; Gobbetti, M.; Auricchio, R.; Mase, R.D.; Landolfo, F.; Paparo, F.; Di Cagno, R.; De Angelis, M.; Rizzello, C.G.; Cassone, A.; et al. Safety for patients with coeliac disease of baked goods made of wheat flour hydrolysed during food processing. Clin. Gastroenterol. Hepatol. 2011, 9, 24-29. [CrossRef] [PubMed]

25. Loponen, J.; Sontag-Strohm, T.; Venäläinen, J.; Salovaara, H. Prolamin hydrolysis in wheat sourdoughs with differing proteolytic activities. J. Agric. Food Chem. 2007, 55, 978-984. [CrossRef]

26. Di Cagno, R.; De Angelis, M.; Lavermicocca, P.; De Vincenzi, M.; Giovannini, C.; Faccia, M.; Gobbetti, M. Proteolysis by sourdough lactic acid bacteria: Effects on wheat flour protein fractions and gliadin peptides involved in human cereal intolerance. Appl. Environ. Microb. 2002, 68, 623-633.

27. Wieser, H.; Vermeulen, N.; Gaertner, F.; Vogel, R.F. Effects of different Lactobacillus and Enterococcus strains and chemical acidification regarding degradation of gluten proteins during sourdough fermentation. Eur. Food Res. Technol. 2008, 226, 1495-1502. [CrossRef]

28. Gerez, C.L.; Rollán, G.C.; de Valdez, G.F. Gluten breakdown by lactobacilli and pediococci strains isolated from sourdough. Lett. Appl. Microbiol. 2006, 42, 459-464. [CrossRef]

29. Stepniak, D.; Spaenij-Dekking, L.; Mitea, C.; Moester, M.; de Ru, A.; Baak-Pablo, R.; van Veelen, P.; Edens, L.; Koning, F. Highly efficient gluten degradation with a newly identified prolyl endoprotease: Implications for coeliac disease. Am. J. Physiol. Gastrointest. Liver Physiol. 2006, 291, G621-G629. [CrossRef]

30. Lopponen, J. Prolamin Degradation in Sourdough. Ph.D. Dissertation, University of Helsinki, Helsinki, Finland, 2006; p. 77.

31. Codex Alimentarius Commission. Codex Standard 118-1979 (Revised 2008), Foods for Special Dietary Use for Person Intolerant to Gluten; FAO: Rome, Italy, 2008.

32. Kahlenberg, F.; Sanchez, D.; Lachmann, I.; Tuckova, L.; Tlaskalova, H.; Méndez, E.; Mothes, T. Monoclonal antibody R5 for detection of putatively coeliac-toxic gliadin peptides. Eur. Food Res. Technol. 2006, 222, 78-82. [CrossRef]

33. Heredia-Sandoval, N.G.; de la Barca, A.C.; Carvajal-Millán, E.; Islas-Rubio, A.R. Amaranth addition to enzymatically modified wheat flour improves dough functionality, bread immunoreactivity and quality. Food Funct. 2018, 9, 534-540. [CrossRef] [PubMed]

34. Walter, T.; Wieser, H.; Koehler, P. Degradation of gluten in wheat bran and bread drink by means of a proline-specific peptidase. Nutr. Food Sci. 2014, 4, 293-299. [CrossRef]

35. Mohan Kumara, B.V.; Sarabhaia, S.; Prabhasankara, P. Targeted degradation of gluten proteins in wheat flour by prolyl endoprotease and its utilization in low immunogenic pasta for gluten sensitivity population. J. Cereal Sci. 2019, 89, 59-67. [CrossRef]

36. Van Eckert, R.; Bond, J.; Rawson, P.; Klein, C.L.; Stern, M.; Jordan, T.W. Reactivity of gluten detecting monoclonal antibodies to a gliadin reference material. J. Cereal Sci. 2010, 51, 198-204. [CrossRef] 
37. Akagawa, M.; Handoyo, T.; Ishii, T.; Kumazawa, S.; Morita, N.; Suyama, K. Proteomic analysis of wheat flour allergens. J. Agric. Food Chem. 2007, 55, 6863-8670.

38. Lookhart, G.L.; Bean, S.R. Improvements in cereal protein separations by capillary electrophoresis: Resolution and reproducibility. Cereal Chem. 1996, 73, 81-87.

(C) 2020 by the authors. Licensee MDPI, Basel, Switzerland. This article is an open access article distributed under the terms and conditions of the Creative Commons Attribution (CC BY) license (http://creativecommons.org/licenses/by/4.0/). 